\title{
Differences in the Reliability of Fair Value Hierarchy Measurements: A Cross-Country Study
}

\author{
Chu Yeong Lim", Gary Pan $^{2}$, Kevin Ow Yong ${ }^{3, *}$ \\ ${ }^{1}$ Nanyang Business School, Nanyang Technological University, Singapore \\ ${ }^{2}$ School of Accountancy, Singapore Management University, Singapore \\ ${ }^{3}$ Design and Specialized Business Cluster, Singapore Institute of Technology, Singapore
}

Email address:

chuyeong.lim@ntu.edu.sg (C. Y. Lim), garypan@smu.edu.sg (G. Pan), kevin.owyong@singaporetech.edu.sg (K. Ow Yong)

${ }^{*}$ Corresponding author

\section{To cite this article:}

Chu Yeong Lim, Gary Pan, Kevin Ow Yong. Differences in the Reliability of Fair Value Hierarchy Measurements: A Cross-Country Study. Journal of Finance and Accounting. Vol. 8, No. 4, 2020, pp. 199-207. doi: 10.11648/j.jfa.20200804.15

Received: June 19, 2020; Accepted: July 16, 2020; Published: August 5, 2020

\begin{abstract}
Prior research suggests there are significant differences in how investors perceive the reliability of fair values. An unaddressed question in this stream of research is whether cross-country differences in institutional factors can mediate differences in reliability for the fair value hierarchy measurements. We contribute to the research on fair value accounting by examining the impact of institutional factors toward the perceived reliability of fair value measurements in an international context. Based on an international sample of banks across twenty different countries, we find that the probability of crash risk is lower among countries with better financial development infrastructure, greater level of trust, tighter security regulations and higher level of disclosure requirements. These results apply to Level 1 assets but not to Level 2 and Level 3 assets. We also document that these cross-country factors improve the trading volume of our sample banks. Our study provides early evidence suggesting that fair value measurements across the fair value hierarchy are impacted by a country's institutional background and financial development as well as the extent of its securities regulation and disclosure level. Our study suggests that there are ongoing concerns toward opaque fair values which are not fully eliminated by institutional differences. In addition, these differences matter in influencing investor willingness to trade in these stocks.
\end{abstract}

Keywords: Fair Value Accounting, Institutional Factors, Reliability

\section{Introduction}

This study examines whether institutional country differences can influence investor perceptions towards the reliability of fair value hierarchy measurements. Prior research documents that investors perceive reliability concerns toward the more subjective fair value measurements (i.e., Level 2 and 3 fair value measurements) relative to fair value measurements that are derived directly from market prices (i.e., Level 1 fair value measurements). An unaddressed question in this stream of research is whether cross-country institutional factors can moderate differences in reliability across the fair value hierarchy measurements given that institutional factors are important toward the enforcement of financial reporting [8]. In our study, we examine whether differences across countries in terms of its sophistication of financial development, level of trust in a country, the extent of security regulations, and the amount of disclosure requirements will affect differences in the reliability of reported fair values.

This issue is important because much of the controversy regarding fair value accounting stems from concerns regarding the reliability of inputs that are used in measuring fair values (Ryan 2008). While Level 1 fair value measurements are less controversial, the use of Level 2 and Level 3 fair value inputs (otherwise known as the mark-to-model approach) has generated tremendous concern and interest among standard setters, regulators and academics because the measurement of fair values based on these inputs are perceived to involve a certain degree of subjectivity and uncertainty $[6,26,32,34]$.

Prior research on fair value hierarchy measurements tend to focus on US firms due to availability of data on reported 
fair values. Consequently, there are relatively less studies that examine fair value hierarchy reported numbers in the financial statements in an international setting. We obtain our data from the SNL Global coverage database that provides international coverage of banks' fair value data both within and outside US. Based on this database, we are able to obtain cross-country data on fair value measurements across 20 different countries located in Americas, Europe, and the Asia-Pacific region.

We use four different country-level measures to test differences regarding the reliability of fair value measurements in an international context. Our country variables are based on various World Bank surveys that provide significant cross-sectional variation to our sample countries. Our first country level variable measures the extent of financial development in a country based on the level of sophistication of the country's stock market and the level of financial intermediaries in extending credit to the economy. This measure is also viewed as a country-level financial constraint measure. This is because richer countries typically have higher quality institutions and laws in general, and these countries tend to be associated with a better financial development environment regardless of the content of these laws and security enforcement [23].

Our second cross-country level variable measures the overall level of trust in the country. We believe trust is an important concept in accounting because the value of accounting lies in how much investors and other stakeholders trust the financial statements. This is especially so in situations where there appears to be significant concerns toward reported accounting information that involves professional estimates and subjective judgments, such as fair value measurements [4, 7]. Fair value measurements, especially those measurements that involve Level 3 inputs, require considerable amount of subjectivity and measurement uncertainty. Hence, cross-country differences in the overall level of trust might impact the extent to which market participants rely on fair value measurements in their investing decisions [28].

Our third country variable measures the extent of security regulations enforced within the country. This measure is a proxy for the degree of investor protection through security laws and other legislation. We use a composite measure of the mean of the disclosure index, the liability standard index, and the public enforcement index to capture this construct (La Porta et al. 2006). Finally, our fourth country variable measures the amount of disclosure requirements within a country. Following Hail and Leuz (2006), our disclosure requirements index variable is defined as the arithmetic mean of these various measures - Prospectus, Compensation, Shareholders, Inside Ownership, Irregular Contracts and Transactions.

We examine whether these four institutional factors will impact the probability of crash risk, return synchronicity and trading volume in relation to reported fair values in the banks' balance sheets. Crash risk relates to the probability of stock market crash in a firm's stock price as a result of a revelation of negative news that lead investors to significantly downgrade their assessments of a firm's prospects [21-22]. Prior studies on crash risk suggest that this phenomenon is exacerbated when a firm has a greater level of asset opacity in its financial reporting. To the extent that Level 2 and 3 fair value measurements are less transparent than Level 1 fair value measurements (market-based prices), information dissemination relating to changes in these reported amounts might exacerbate stock price crash risk.

Return synchronicity relates to the extent a firm's stock return varies with market return. Extant research on stock market synchronicity suggests that the explanatory power of firm's stock return with the market return is lower when there is greater transparency and more complete revelation of firm-specific information [27]. With regard to fair value accounting, fair values are purported to be more transparent and relevant to decision makers. However, differences across the subjectivity of fair value inputs might impact the extent to which fair value reporting provides useful information to financial statement readers. To the extent that fair values are reliable and relevant, we expect return synchronicity to be lower. In contrast, opaque fair values might increase market return synchronicity in a firm's stock returns. Our third outcome variable is trading volume, which measures the extent to which an investor is willing to trade in the shares of firms with reported fair values. If investors trust the reporting reliability of fair values, we expect trading volume to be high. Conversely, if reported fair values represent significant concerns to market participants, we expect trading volume in the shares of these firms to be muted.

Our first set of tests examines whether institutional factors account for country variation in stock price crash risk and return synchronicity in reported fair values. We find consistent empirical evidence to suggest that institutional factors are able to mediate the relation between Level 1 fair value measurements and stock price crash risk. Specifically, the extent of a country's financial development, overall level of trust, the extent of security regulations, and the amount of disclosure requirements are negatively associated with stock price crash risk for reported Level 1 fair values. However, these institutional factors appear to have little effect in mediating the relation towards alleviating stock price crash risk for Level 2 and Level 3 fair value measurements. Likewise, we find corroborating evidence for Level 1 fair value measurements in our return synchronicity tests but these institutional factors do not affect how reported Level 2 and Level 3 fair value measurements affect crash risk and return synchronicity.

We also examine the impact of institutional factors on trading volume. Specifically, we examine whether institutional factors are able to mediate the relation between reported fair values and trading volume. In these results, we find strong evidence that institutional factors have a positive effect on reported fair values across all three fair value designations. The incremental impact on trading volume is especially striking for the Level 2 and Level 3 fair value measurements. We interpret these results to suggest that 
institutional factors matter greatly to market participants in considering whether to trade the shares of banks that report significant amounts of Level 2 and Level 3 assets on their balance sheets. It appears that investors are relatively disinclined to invest in the companies of countries that have poor financial development and security regulation, low overall societal trust and lax disclosure requirements. We conjecture that the relative lack of investor interest in these firms is because there might be questionable doubts regarding the reliability of fair value measurements on these firms' balance sheets.

We contribute to the research on fair value accounting by examining the impact of institutional factors toward the perceived reliability of fair value measurements in an international context. Prior studies have not examined fair value measurements in a cross-country study presumably because of unavailability of data for reported fair value hierarchy measurements. Our study provides early evidence suggesting that fair value measurements across the fair value hierarchy are impacted by a country's institutional background and financial development as well as the extent of its securities regulation and disclosure level.

The next section provides our hypotheses development and the institutional background surrounding fair value measurements and the regulatory environment. Section 3 describes the sample and empirical measures. Section 4 discusses the test results and Section 5 concludes.

\section{Hypothesis Development}

\subsection{Fair Value Hierarchy}

The issuance of FAS 157 (ASC 820) in September 2006 by the Financial Accounting Standards Board (FASB) mandated a division of different classes of assets and liabilities into Level 1 observable inputs from quoted prices in active markets, Level 2 indirectly observable inputs from quoted prices of comparable items in active markets, identical items in inactive markets, or other market-related information and Level 3 unobservable, firm- generated inputs [12]. Hence, FAS 157 provides additional classification information on fair value measurements by categorizing fair value assets and liabilities into three distinct groups on the basis of the inputs and methodologies used to assess fair value. Improved disclosure requirements of methods and inputs in determining fair value were also formalized in this accounting standard.

Under SFAS 157 Fair Value Measurements, fair value is defined as the "price that would be received to sell an asset or paid to transfer a liability in an orderly transaction between market participants at the measurement date." The International Accounting Standards Board (IASB) similarly stipulates the disclosure requirements for the fair value hierarchy information as required by IFRS 7 Financial Instruments: Disclosures [19]. This accounting standard requires reporting entities to provide disclosure of information about the significance of financial instruments to the firm, and the nature and extent of risks arising from those financial instruments, both in qualitative and quantitative terms. Specific disclosures are required in relation to transferred financial assets and a number of other matters.

Subsequently, the fair value hierarchy disclosure requirements are consolidated in IFRS 13 Fair Value Measurement as the International Accounting Standards Board wanted to designate a single framework for measuring fair value in this IFRS as well as disclosures about fair value measurements [20]. Similar to the FASB, the Standard defines fair value based on an 'exit price' notion and uses a 'fair value hierarchy', which results in a market-based, rather than entity-specific, measurement. IFRS 13 was originally issued in May 2011. It applies to annual periods beginning on or after 1 January 2013.

Since the advent of ASC 820 and IFRS 13, various studies have examined how market participants respond to the subjectivity of inputs used in each of these fair value levels. Song et al. (2010) and Riedl and Serafeim (2011) were the early studies that investigate the effect of different fair value levels on market pricing and information risk of assets respectively whereas Goh et al. (2015) and Chung et al. (2017) provide further cross sectional and longitudinal studies that build upon the earlier studies. There have also been studies that examine how the fair value hierarchy measurements affect analysts in interpreting reported fair values in the financial statements [2, 26].

The extant research generally finds that the value relevance of Level 1 and Level 2 fair values is greater than the value relevance of Level 3 fair values. For example, Song et al (2010) find that the valuation coefficient of Level 3 assets is significantly less positive than those of Level 1 and Level 2 assets. In addition, the authors also find that the valuation coefficient of Level 3 liabilities is significantly more negative than those of Level 1 and Level 2 liabilities. As with Level 3 assets, these results appear to be consistent with the notion that Level 3 liabilities suffer from unreliability and other measurement difficulties. Hence, investors appear to decrease the weight they place on less reliable fair value measurements leading to a lower valuation for Level 3 financial instruments.

Another influential fair value hierarchy study that examines whether information risk in reported fair values have economic consequences is Riedl and Serafeim (2011). The authors document that firms with greater exposure to more opaque financial assets, as reflected in the level 3 fair value designation, exhibit a higher cost of capital as shown in relatively higher implied asset betas. Their study suggests that greater exposure to more opaque financial instruments leads to higher information risk, and consequently, resulted in a higher cost of capital. These results are consistent with the findings of other studies showing that investors attribute a lower value relevance for Level 3 fair values [6, 14].

Specifically, Riedl and Serafeim (2011) examine variation in cost of capital among firms that report fair values in the following manner. First, they derive an empirical model allowing asset specific estimates of implied betas and find evidence that firms with greater exposure to Level 3 financial assets exhibit higher betas relative to those assets that are 
designated as either Level 1 or Level 2. In several cross-sectional tests, they also find further evidence that this difference in implied betas across fair value designations is more pronounced for firms with ex ante lower-quality information environment. Thus firms with higher analyst following, higher market capitalization, lower analyst forecast errors, or lower analyst forecast dispersion attenuate the relation between information risk and exposure to Level 3 assets. The authors thus suggest that firms with more opaque financial assets bear a higher cost of capital because of greater information risk associated with these assets. On the other hand, they recommend that differences in firms' information environments can mitigate information risk across the fair value designations.

The focus of this stream of research is primarily confined to firms in the financial sector (e.g., banks, mortgage companies, insurance companies with a large concentration of financial instruments reported of fair value that were affected by the implementation of FAS 157). Notably, many of these studies use firms within the USA. Our study differs from this stream of research as we include firms outside the USA in our sample. Prior research has shown that there are significant international differences in IFRS practice which might create problems for investor confidence and comparability [29-30]. In particular, we focus on the impact of countries' institutional factors in influencing investors' perceptions regarding the reliability of these fair value measurements.

\subsection{Institutional Factors}

Extant research examines the impact of securities laws and stock market development on financial markets [3, 24]. These studies generally find that securities laws and regulatory enforcement are important factors in influencing the development of financial markets. In addition, the availability of laws to mandate disclosure requirements and facilitate private enforcement through liability rules has also been shown to benefit stock markets. On the other hand, in the context of fair value measurements, the link between institutional environmental factors and the reliability of fair values has not been fully examined.

One interesting study that examines fair value reporting and the link to institutional environmental factors is He et al. (2012). The authors find that fair value accounting may induce earnings management under certain conditions. In particular, earnings management activities arising from fair value changes are more pronounced among firms in regions with weaker institutions (e.g., poor legal environment) and poor corporate governance practices (e.g., politically connected managers). However, their study is based on a sample of A-share listed companies that are based in China. In contrast, our sample firms span across countries around the world. In addition, we select our sample from firms in the banking and financial industries whereas $\mathrm{He}$ et al (2012) use firms in nonfinancial industries.

We are keen to examine how institutional factors affect investors' perception of reported fair values because we believe that these factors influence the level of trust toward acceptance of fair value accounting. Over the decades, there is an emerging literature on trust and its function and importance in society. Trust plays an important role in the social and economic world. It is broadly defined as the subjective probability that an individual assign to the events of a potential counterparty performing an action that is beneficial or at least not harmful to that individual [13]. A group of researchers investigates the role of trust in economic development and economic efficiency $[15,35]$. In the context of our study, trust has been alluded to but has not been extensively examined in a fair value accounting setting.

A recent trend in the literature is to use broad measures of trust from existing surveys to conduct studies related to trust. For example, Nanda and Wysocki (2013) investigate the relation between financial reporting transparency and societal trust. More recently, Lim et al. (2018) conduct a survey of accounting professionals from members of the Institute of Singapore Chartered Accountants (ISCA) and the Institute of Valuers and Appraisers of Singapore (IVAS) to solicit their opinions as to whether they trust fair value reporting. Among their findings, they find that a high percentage of their respondents indicate "a high level of distrust about Level 3 fair value estimates." These results are especially telling because the survey respondents comprise preparers of financial statements as well as those who attest to the accuracy of these reported financial statements.

Trust is an important concept in accounting because the value of accounting lies in how much investors and other stakeholders trust the financial statements. Fair value measurements, especially those measurements that involve Level 3 inputs, require considerable amount of subjectivity and measurement uncertainty [7]. Recent developments in accounting standards have also provided firms with more discretion to decide what measurement basis to adopt. With a move toward more fair value accounting in financial reporting, investors may become more skeptical about reported fair value information in the financial statements.

\subsection{Crash Risk}

The theoretical crash risk model in Jin and Myers (2006) postulates that increased opacity in financial reporting lead to managers being able to withhold bad news from public disclosure. However, managers are only able to withhold bad news up to a certain threshold. Once the threshold is met, the accumulated bad news are disclosed all at once, and market participants surprised by these news, will start to exit the market together, resulting in a stock price crash.

A necessary condition for this phenomenon is the ability of managers to control public access to negative information about firm value, either through financial reporting or other mechanisms. Prior research has examined the impact of financial reporting transparency and accounting standards on crash risk [9, 18]. Hutton et al. (2009) use a firm-specific measure of opacity and find that more opaque firms are more prone to stock price crashes although the effect weakens in the post-Sarbanes-Oxley period. DeFond et al. (2015) test whether mandatory IFRS adoption affects firm-level crash 
risk. Their results indicate that increased transparency from IFRS adoption has the effect of reducing crash risk among nonfinancial firms, but more selectively among financial firms, presumably because of the countervailing effects of fair value accounting to crash risk.

Extant research shows mixed results on this issue. On the one hand, fair value accounting might better reflect firms' true underlying performance, thereby reducing crash risk [5]. On the other hand, it might also introduce greater measurement errors in financial reporting, which reduce investors' ability to observe firms' true underlying performance [11]. In the context of fair value hierarchy measurements, the fair value estimates of more opaque assets (i.e., Level 2 and 3 assets) may contain relatively more measurement errors, thus increasing financial reporting opacity.

\subsection{Return Synchronicity}

Extant research on return synchronicity suggests that stock returns are more synchronous in less developed markets. For example, Morck et al. (2000) find that in emerging markets like China, Malaysia, and Poland, over $80 \%$ of stocks often move in the same direction in a given week. In contrast, Denmark, Ireland, and the United States lack any instances of more than $57 \%$ of the stocks moving in the same direction during any week. The authors suggest that this is because stock markets in poor economies are generally less developed. Thus, there is poorer information transfer, which impede the capitalization of firm-specific information into stock prices. This effect would reduce firm-specific stock price variation and increase stock return synchronicity with the market return.

The notion that greater transparency and more complete revelation of firm-specific information will reduce return synchronicity has been extensively examined $[1,10]$. In the context of fair value measurements, it remains to be seen whether fair values facilitate or worsen information sharing. This is especially so in relation to institutional factors in an international setting. For example, it is possible that country specific factors such as the extent of financial development or the effectiveness of security regulations can have a mediating effect on stock prices through reported fair values.

\subsection{Hypotheses Development}

In this study, we use an international setting to study whether cross-country variation in institutional factors account for differences in the transparency of Level 2 and Level 3 fair value measurements. We use four empirical measures, namely, the extent of a country's financial development, security regulations, disclosure requirements and the overall level of trust in a country, to proxy for cross-country differences in a firm's business environment.

We conjecture that the usefulness of fair value accounting depends on individual countries' implementation of accounting rules and the proper enforcement of these rules. It also depends on how much and how willing market participants trust the reliability of fair values. To the extent that there are cultural and institutional factors that will influence the level of trust in a society, our study enables us to examine whether trust plays a mediating role toward the usefulness of fair values.

As previously stated, studies that have examined crash risk and return synchronicity suggest that opacity in financial reporting will increase the occurrence of crash risk. In fair value accounting research, reliability concerns toward reported fair values remain an ongoing concern [17]. If reported fair value measurements are able to increase transparency in financial statements, we will expect market participants to be informative about firm's fundamentals when there is greater use of fair values in the financial statements. In our setting, we are interested to examine whether there are cross-country differences in the perceived reliability of reported fair values, and whether these differences will impact market outcomes.

We state our first set of hypotheses, in alternative form, as follows:

H1a: A higher proportion of reported fair values is negatively associated with the probability of crash risk when the sophistication of a country's financial development is higher, a country's level of societal trust is higher, the extent of security regulations is greater, and when there are more disclosure requirements.

H1b: A higher proportion of reported fair values is negatively associated with the return synchronicity when the sophistication of a country's financial development is higher, a country's level of societal trust is higher, the extent of security regulations is greater, and when there are more disclosure requirements.

A second research question that we examine in this paper is whether market participants are more willing to trade in the shares of companies with a higher proportion of reported fair values in their balance sheets among countries with stronger institutional background (i.e., more well-regulated, better disclosure regimes) than in countries that have relatively weaker institutions and regulations. This question is particularly salient with regard to reported Level 2 and 3 fair values given the relatively lack of transparency in determining these reported amounts.

We postulate that there is a cross-sectional difference in the willingness of investors to trade in the shares of banks with high amounts of reported fair values in their balance sheets in countries with strong institutional safeguards versus countries with relatively poor institutional safeguards. As with our first hypothesis, we examine countries' institutional factors relating to its financial development, overall trust level, sophistication of security regulations and level of disclosure requirements.

We state our second hypothesis, in alternative form, as follows:

$\mathrm{H} 2$ : A higher proportion of reported fair values is positively associated with trading volume when the sophistication of a country's financial development is higher, a country's level of societal trust is higher, the extent of security regulations is greater, and when there are more disclosure requirements. 


\section{Research Design}

We obtain our fair value data from the SNL Global coverage database. This database provides international coverage of banks' fair value data that is based on the fair value hierarchy classification, including countries in Americas, Europe, and Asia-Pacific region. We obtain our capital market data from Datastream to compute price and other market variables. We exclude sample firms that do not have a matching ISIN number with the SNL Global coverage database. Our sample period is from 2007 - 2015. We obtain an initial sample of 6,485 bank-year observations across 20 different countries with reported Level 1, 2 and 3 assets from this dataset.

We use four different country-level measures in our regression analyses. We develop our composite-level variables from various World Bank surveys. Our first country level measure is Financial Development $(F D)$. This variable measures the extent of financial development in a country along two dimensions. Specifically, it is measured as the sum of stock market development index and financial intermediary development index. The stock market development index is the sum of market capitalization over GDP, total value traded over GDP, and total value traded over market capitalization. The financial intermediary development index is the sum of liquid liabilities over GDP and the credit going to the private sector over GDP and is typically regarded as a country-level financial constraint measure.

Our second cross-country level variable is Trust. Our measure of trust is based on the World Value Survey, defined by asking respondents the following question: "Generally speaking, would you say that most people can be trusted or that you need have to be very careful in dealing with people?" The level of trust in each country is based on the percentage of respondents replying the following response "most people can be trusted". This measures ranges from $0 \%$ (absolute distrust) to $100 \%$ (absolute trust).

Our third measure is Security Regulation $(S R)$. This is a country-level measure to proxy for the level of security laws and investor protection. Following Hail and Leuz (2006), this variable is defined as the mean of the disclosure index, the liability standard index, and the public enforcement index ( $\mathrm{La}$ Porta et al. 2006). Our fourth country level measure is Disclosure. Following Hail and Leuz (2006), this variable is defined as the arithmetic mean of Prospect, Compensation, Shareholders, Inside Ownership, Irregular Contracts and Transactions.

We estimate the following regressions to test our hypotheses:

$$
\begin{array}{r}
C R A S H=\beta_{0}+\beta_{1} F V A 1+\beta_{2} F V A 23+\beta_{3} \text { CROSS-COUNTRY }+\beta_{4} F V A 1 * \text { CROSS-COUNTRY }+\beta_{5} F V A 23 * \text { CROSS-COUNTRY }+ \\
\beta_{6} R O A+\beta_{7} L E V E R A G E+\beta_{8} M 2 B+\beta_{9} S I Z
\end{array}
$$

$$
\begin{array}{r}
\mathrm{SYN}=\beta_{0}+\beta_{1} \mathrm{FVA} 1+\beta_{2} \mathrm{FVA} 23+\beta_{3} \text { CROSS-COUNTRY }+\beta_{4} \mathrm{FVA} 1 * \text { CROSS-COUNTRY }+\beta_{5} \text { FVA } 23 * \text { CROSS-COUNTRY }+ \\
\beta_{6} \text { ROA }+\beta_{7} \text { LEVERAGE }+\beta_{8} \mathrm{M} 2 \mathrm{~B}+\beta_{9} \text { SIZE }
\end{array}
$$

$$
\begin{array}{r}
\text { VOLUME }=\beta_{0}+\beta_{1} F V A 1+\beta_{2} F V A 23+\beta_{3} \text { CROSS-COUNTRY }+\beta_{4} F V A 1 * C R O S S-C O U N T R Y+\beta_{5} F V A 23 * C R O S S-C O U N T R Y+ \\
\beta_{6} R O A+\beta_{7} L E V E R A G E+\beta_{8} M 2 B+\beta_{9} S I Z E
\end{array}
$$

where CRASH is defined as the negative skewness of firm-specific weekly returns over the fiscal year period based on Jin and Myers (2006). SYN is the return synchronicity of a firm's stock returns with market returns. It is calculated as the $\log (\mathrm{R} 2 / 1$ - R2) estimated from regressing weekly market return during the fiscal year on the firm's stock return. VOLUME is the mean of weekly trading volume during the fiscal year. $F V A 1$ is Level 1 fair value assets scaled by total outstanding shares during the fiscal year. FVA23 is the sum of Level 2 and Level 3 fair value assets scaled by total outstanding shares during the fiscal year. The cross-country variables are namely, Financial Development (FD), Trust, Security Regulation (SR), and Disclosure, as previously defined. In our regression analyses, our cross-country variables are indicator variables that equal one if their scores are above the median value, and zero otherwise.

Following Hutton et al. (2009), we use the following firm-specific variables as control variables. SIZE is calculated as the log of total assets, $R O A$ is earnings before extraordinary items divided by total assets. LEVERAGE is the book value of total liabilities scaled by total assets, and $M 2 B$ is the ratio of the market value of equity to the book value of equity. We also incorporate year and country fixed effects in our regression specifications.

\section{Empirical Results}

\subsection{Descriptive Statistics}

We report our fair value measures scaled by the total assets of the bank. The mean (median) value of FVA1 is 0.021 (0.000), whereas the mean (median) value of FVA2 is 0.164 (0.145), and the mean (median) value of $F V A 3$ is $0.018(0.007)$. The descriptive statistics are generally consistent with the results reported in prior studies that indicate Level 2 assets represent the largest proportion of fair value assets on the bank's balance sheet.

For our dependent variables, the mean (median) value of our crash risk measure is -0.051 (-0.055). The mean (median) value of our return synchronicity measure is $-2.622(-2.091)$. Finally, the mean (median) value of our trading volume measure is $2.373(0.020)$. For our country level variables, the mean (median) value of Financial Development $(F D)$ is 800.39 (759.39).

We find that there is substantial variation in the level of financial development across our sample countries. Across our sample countries, countries with well-developed financial services sectors such as Hong Kong (1711.42), USA (838.74), Switzerland (799.64), and UK (759.23) scored high on this 
measure, whereas countries such as Pakistan (105.12), and Philippines (188.12) have relatively lower scores.

The mean (median) value of TRUST is 0.371 (0.382) indicating that about $38 \%$ of the population in our sample expressed a certain level of trust towards others in business dealings. Among the countries that have higher level of trust are Australia (0.533), Finland (0.588), Netherlands (0.602) and Sweden (0.680). In contrast, Philippines (0.028) and Malaysia (0.085) are countries that indicate the lowest level of trust towards others in our sample countries. Our third cross-country variable is Security Regulation (SR). Across our sample countries, high $S R$ scores are found in countries such as USA (2.900), Canada (2.717), and Singapore (2.527) whereas countries that report low level of security regulation are Germany (0.633), Sweden (1.358) and Italy (1.370). Our fourth cross-country variable is Disclosure. Similar to our Security Regulation variable, we find that countries that have relatively high level of disclosure requirements are USA (1.000), Singapore (1.000) and Canada (0.917). In contrast, countries with low disclosure scores include Germany (0.417), Finland (0.500) and Netherlands (0.500).

\subsection{Crash Risk Analysis}

We report the results of our regression analyses from regressing crash risk on our various cross-country variables. We combine Level 2 and Level 3 assets (FVA23) to differentiate this variable from $F V A 1$ which are solely based on market prices when estimating fair values. Prior literature asserts that Level 1 assets are more reliable because they rely directly on market prices in determining fair values. In contrast, FVA23 represent fair values of financial assets that are subject to some form of managerial discretion during the fair value estimation process.

Prior studies on crash risk suggest that greater transparency will reduce the probability of crash risk. However, these studies do not examine the interaction effect of cross-country effects on reported fair value measurements. In our tests, we document significant cross-country effects across our interaction variables of interest for Level 1 assets. In particular, we find a negative association between Level 1 fair value assets and crash risk among countries with a higher level of Financial Development, Trust, Security Regulation and Disclosure. The coefficients on our interaction variables on Level 1 assets are consistent across all our measures. In particular, they are negative and statistically significant for FVA1 x FD (-1.639, t-stat=-2.420), FVA1 x Trust $(-1.208$, t-stat=-1.672), FVA1 $x$ SR $(-1.782$, t-stat=-2.571), and FVA1 $x$ Disclosure (-1.712, t-stat $=-2.654)$.

Among these variables, FVA1 $x$ Disclosure is statistically significant at the 0.01 level and FVA1 $x$ FD and FVA1 $x$ SR are significant at the 0.05 level whereas FVA1 $x$ Trust is significant at the 0.10 level. These results lend support to various findings in the fair value accounting research stream that suggests the role of extensive disclosures in boosting confidence among investors and lead to greater trust in these reported fair values [33]. Overall, we interpret these results to suggest that there is a cross-country effect for crash risk among countries with better developed financial development infrastructure, greater security regulations, and higher level of trust and disclosure requirements. However, it appears that these cross-country improvements impact differences in crash risk for Level 1 assets but not in Level 2 and Level 3 assets. That is, we do not find any cross-country variables that reduce the probability of crash risk inherent in non-market based fair values (i.e., Level 2 and 3 assets) in these tests.

We report the results of regressing return synchronicity on our cross-country variables. These test results corroborate our earlier tests using crash risk as the dependent variable. We find statistically significant cross-country effects in countries with greater security regulation and disclosure requirements. However, we do not find statistically results for Financial Development and Trust. Consistent with the results in our crash risk tests, the impact from cross-country effects on return synchronicity as a result of better security regulations and disclosure requirements apply only to Level 1 fair value assets. Specifically, the coefficients on our interaction variables on Level 1 assets are negative and statistically significant for FVA1 $x$ SR (-6.232, t-stat=-4.122), and FVA1 $x$ Disclosure (-2.650, t-stat $=-1.880)$.

On the other hand, we do not find any statistical difference with regard to the incremental impact to return synchronicity for Level 2 and 3 assets across any of these four cross-country variables. One interpretation of both sets of results is that the cross-country differences in financial infrastructure, security regulations, and the level of trust and disclosure requirements are not sufficiently strong enough to be able to alleviate all reliability concerns toward Level 2 and 3 assets. Hence, asset opacity in Level 2 and 3 assets remain high even in well-developed financial markets. For example, there were reported reliability concerns over Deutsche Bank's Level 3 assets holdings as they were reported on its balance sheet [31]. This is so even through Deutsche Bank is the largest German lender, and Germany has well developed financial infrastructure and security regulations.

We believe that the interpretation of these results is consistent with standard setters' ongoing concerns that market participants are still distrustful of certain financial instruments that are reported at fair value. It thus appears that there is still much improvement to be made before shareholders and other market participants are able to fully trust the accuracy of fair value measurements as they are reported in financial statements and rely upon these reported figures without any doubt or questions.

\subsection{Trading Volume Analysis}

We report the results of regressing trading volume on our cross-country variables. In countries with better quality financial infrastructure, greater security regulation, and higher level of trust and disclosure, there appears to be greater confidence towards reported fair values, which translates to a higher trading volume among the shares of these banks. The strongest country effects reside in differences in security regulations and disclosure 
requirements. Specifically, we find positive associations for our FVA1 and FVA2 interaction cross-country variables among countries with high level of security regulation and disclosure compared with countries with lax security regulation and poor disclosure requirements. The coefficients for FVA1 $x$ SR and FVA2 $x$ SR are 24.81 and 18.57 respectively, both statistically significant at the 0.01 level. Likewise, the coefficients for FVA1 $x$ Disclosure and FVA2 $x$ Disclosure are 16.33 and 19.59 respectively, also statistically significant at the 0.01 level. These results suggest that tighter security regulations and greater disclosure requirements inspire investor confidence to trade in the shares of banks with a large proportion of fair value assets.

Apart from the above results, we also find that investors are more willing to trade in the shares of banks with Level 2 and 3 assets in countries with more well-developed financial development infrastructure $(F D)$, and in countries where there is a greater level of trust. Overall, the results suggest that there is a significant cross-country effect to differences in trading volume. It appears that investors are less reserved toward banks with greater reported Level 2 and Level 3 fair values if these banks are located in countries with better security regulations and disclosure requirements. We also find similar results for Level 1 assets in the predicted direction although the results are not statistically significant. These results suggest that a country's level of financial development and the cross-country differences in a country's level of trust plays a less important role in influencing trading volume for banks with different amounts of Level 1 assets, presumably because there is less concern toward Level 1 assets in the first place.

Overall, we document that there are significant cross-country differences in the level of trading volume among banks with different amounts of reported Level 2 and Level 3 assets. It appears that cross-country effects have a mediating effect on trading volume with regard to differences in reported fair values in banks' balance sheets.

\section{Conclusion}

In this study, we examine how a country's institutional factors are able to play a mediating role in affecting reliability concerns towards fair value measurements. Using various empirical measures to proxy for a country's level of financial development, extent of security regulations and disclosure requirements, as well as its overall level of trust, we find that these institutional factors matter to investors when trading the shares of banks with a high proportion of reported fair values on their balance sheets. Specifically, our tests reveal that investors are relatively disinclined to invest in the companies of countries that have poor financial development and security regulation, low overall societal trust and lax disclosure requirements because there might be questionable doubts regarding the reliability of the fair value measurements on the firms' balance sheets.

We also show whether these institutional factors mediate the relation between the probability of crash risk and return synchronicity. The study of tail events such as crash risk is particularly relevant to debates regarding fair value accounting as it is a policy issue whether firms that have more assets that are fair valued in their balance sheets are more likely to suffer from higher crash risk owing to concerns regarding the transparency of these assets and the subjectivity of the fair value estimation processes. We find empirical evidence suggesting that country's institutional factors are able to mediate the Level 1 fair values, but not Level 2 and 3 fair values.

Our study extends prior research on the fair value hierarchy measurements. We provide empirical evidence that assess how various countries' institutional differences might alleviate significant reliability concerns toward fair value measurements. In doing so, we shed further light toward a better understanding of the usefulness of fair value accounting in relation to various market outcome factors in an international setting. Our study also contributes to the ongoing debate regarding the role of fair value measurements on financial markets.

\section{Acknowledgements}

We wish to thank Jong-Seo Choi (discussant), Dahlia Robinson (discussant), Amine Tarazi (discussant) and conference participants at the 2018 Taiwan Accounting Association Annual Conference and Asian Accounting Associations Conference, 29th Australasian Finance and Banking Conference and the 7th TJAR conference for helpful comments and suggestions. This research is supported by a Ministry of Education Tier 2 (MOE2014-T2-2-137) grant. We also thank Amanda Li and Mingyue Zhang for their research assistance. All errors are our own.

\section{References}

[1] Ashbaugh, H., Gassen, J., \& Lafond, R. (2005). Does stock price synchronicity reflect information or noise? The international evidence. Working paper. University of Wisconsin - Madison

[2] Barron, O., Chung, S. G., \& Yong K. O. (2016). The effect of Statement of Financial Accounting Standards No. 157 fair value measurements on analysts' information environment. Journal of Accounting and Public Policy, 35, 395-416.

[3] Barth, J., Caprio, G., \& Levine, R. (2003). Bank supervision and regulation: What works best? Journal of Financial Intermediation 13, 205-248.

[4] Bell, T. B., \& Griffin, J. B. (2012). Commentary on auditing high-uncertainty fair value estimates. Auditing: A Journal of Practice and Theory, 31, 147-155.

[5] Bleck, A., \& Liu. X. (2007). Market transparency and the accounting regime. Journal of Accounting Research 45: 229 256.

[6] Chung, S. G., Goh, B. W., Ng, J., \& Yong K. O. (2017). Voluntary fair value disclosures beyond SFAS 157's three-level estimates. Review of Accounting Studies, 22, 430-468. 
[7] Christensen, B. E., Glover, S. M., \& Wood, D. A. (2012). Extreme estimation uncertainty in fair value estimates: Implications for audit assurance. Auditing: A Journal of Practice \& Theory, 31, 127-146.

[8] Christensen, H. B. Hail, L., \& Leuz C. (2013). Mandatory IFRS reporting and changes in enforcement. Journal of Accounting and Economics 56 (2-3), 147-177.

[9] DeFond, M. L., Hung, M., Li, S., \& Li, Y. (2015). Does mandatory IFRS adoption affect crash risk? The Accounting Review 90 (1), 265-299.

[10] Durnev, A., Morck, R., Yeung, B., \& Zarowin, P. (2003). Does greater firm-specific return variation mean more or less informed stock pricing? Journal of Accounting Research 41 (5), 797-836.

[11] European Central Bank. 2004. Fair value accounting and financial stability. Occasional Paper Series 13, 3-48.

[12] Financial Accounting Standards Board, (2006). Statement of Financial Accounting Standards No. 157, Fair Value Measurements. Norwalk, CT: FASB.

[13] Gambetta, D. (1988). Trust: Making and breaking cooperative relations. Oxford: Blackwell.

[14] Goh, B. W., Li, D., Ng, J. \& Yong, K. O. (2015). Market pricing of banks' fair value assets reported under SFAS 157 since the 2008 financial crisis. Journal of Accounting and Public Policy, 34 (2), 129-145.

[15] Guiso, L., Sapienza, P., \& L. Zingales, (2004). The role of social capital in financial development. American Economic Review, 94, 526-556.

[16] Hail, L. \& Leuz, C. (2006). International differences in the cost of equity capital: Do legal institutions and securities regulation matter? Journal of Accounting Research, 44 (3): 485-531.

[17] He, X., T. J. Wong, \& Young D. (2012). Challenges for Implementation of fair value accounting in emerging markets: Evidence from China. Contemporary Accounting Research, 29 (2): 538-562.

[18] Hutton, A. P., A. J. Marcus, \& H. Tehranian. (2009). Opaque financial reports, R2, and crash risk. Journal of Financial Economics 94 (1), 67-86.

[19] International Accounting Standards Board. (2006). IFRS 7: Financial Instruments: Disclosure. London, UK: IASB

[20] International Accounting Standards Board. (2011). IFRS 13: Fair Value Measurement. London, UK: IASB
[21] Jin, L., \& Myers, S. (2006). R2 around the world: New theory and new tests. Journal of Financial Economics, 79 (2), 257-292.

[22] Kim, J-B., \& Zhang, L. (2014). Financial reporting opacity and expected crash risk: Evidence from implied volatility smirks. Contemporary Accounting Research, 31 (3), 851-875.

[23] LaPorta, R., Lopez-de-Silanes, F., Shleifer, A., \& Vishny. R. (1999). The quality of government. Journal of Law, Economics and Organization 15 (1), 222-279.

[24] LaPorta, R., Lopez-de-Silanes, F., \& Shleifer, A. (2006). "What Works in Securities Laws?.” Journal of Finance 61 (1), 1-32.

[25] Lim, C. Y., Ng, J., Pan, G., \& Yong, K. O. (2018). Trust in Fair Value Accounting: Evidence from the Field. Working Paper. Singapore Institute of Technology.

[26] Magnan, M., Menini, A., \& Parbonetti, A. (2014). Fair value accounting: Information or confusion for financial markets. Review of Accounting Studies, 20 (1), 559-591.

[27] Morck, R., Yeung, B., \& Yu, W. (2000). The information content of stock markets: Why do emerging markets have synchronous stock price movements? Journal of Financial Economics, 58 (1-2), 215-260.

[28] Nanda, D., \& Wysocki, P. (2013). Trust, External Capital and Financial Transparency. Working paper, University of Miami.

[29] Nobes, C. (2013). The continued survival of international differences under IFRS Accounting and Business Research, 43 (2), 83-111.

[30] Nobes, C. W. \& Zeff, S. A. (2008). Auditors' affirmations of compliance with IFRS around the World: An exploratory study. Accounting Perspectives, 7 (4), 279-292.

[31] Noonan, L. (2016). Balance sheet doubts widen German lender's credibility gap. Financial Times

[32] Riedl, E. J., \& Serafeim, G. (2011). Information risk and fair value: An examination of equity betas. Journal of Accounting Research, 49 (4), 1083-1122.

[33] Ryan, S. G. (2008). Accounting in and for the subprime crisis. The Accounting Review, 83 (6), 1605-1638.

[34] Song, C. J., Thomas, W. B. \& Yi, H. (2010). Value relevance of FAS No. 157 fair value hierarchy information and the impact of corporate governance mechanisms. The Accounting Review, 85 (4), 1375-1410.

[35] Zak, P. J., and Knack, S. (2001). Trust and growth. The Economic Journal, 111, 295-321. 